Matthew Gabriele, "The Chosen Peoples of the Eleventh and Twenty-First Centuries," Relegere: Studies in Religion and Reception 2, no. 2 (20 I 2): 28 I-90.

(c) BY-NC-ND This work is licensed under a Creative Commons Attribution Non-Commercial No Derivatives 3.o License.

Relegere: Studies in Religion and Reception is an independent, open-access academic journal dedicated to the promotion and dissemination of innovative research in reception history, broadly conceived, within and across religious traditions.

www.relegere.org

ISSN I I 79-723 I 


\section{Matthew Gabriele}

\section{The Chosen Peoples of the Eleventh and Twenty- First Centuries}

The idea of a people's election by God is a narrative that attempts to efface contestation over the past, erasing history by constructing new memory. This paper will examine how this functions by comparing two Christian narratives of election. The Franks who participated in the First Crusade (I095-99) thought themselves to be God's new chosen people, who were in the process of reclaiming his favor. Similarly, a streak in contemporary evangelical (Judeo-)Christianity thinks itself at a point in that narrative just before the crusaders, with God showing his anger at his new chosen people (Americans). By understanding this process of narrativization, we understand that the idea of election suggests a course of action, in that it creates a hermeneutic seal around the "insiders," flattens differences among "outsiders," and requires the chosen people to fight back against the agents of God's wrath.

TN I096 CE, Jews were massacred throughout the Rhine and Moselle river Ivalleys by Christians participating in the First Crusade (ca. I 095-99). The entire Jewish communities of Worms, Mainz, and Cologne were annihilated;

Matthew Gabriele is Associate Professor in the Department of Religion and Culture at Virginia Tech. 
some accepted baptism in exchange for their lives, while most were either killed or ritually sacrificed one another to avoid falling into the Christians' hands. At Cologne, the archbishop had dispersed the community into surrounding villages, hoping to spare them the ravages of the crusaders but the apocalyptic sensibilities of the Christians were not to be soothed and they hunted the Jews down, systematically visiting the villages and killing them. At Trier and Metz, the Jewish communities accepted baptism wholesale in order to escape the fate that befell their co-religionists. ${ }^{1}$

In seeking to explain the events of I096, early twelfth-century Hebrew narratives told of a chosen people who had lost their way, who had been punished for their sins, and who hoped to atone for those sins through spectacular acts of devotional violence-Kiddush ha-Shem, sanctification of the divine name through ritual sacrifice (of one another). ${ }^{2}$ The contemporary Christian histories of the First Crusade actually did much the same, telling of a chosen people who had lost their way, but have begun to reclaim God's favor, atoning for their sins through spectacular acts of devotional violence-warfare and massacre in their quest to reclaim Jerusalem. ${ }^{3}$ I do not think it is a coincidence we see such similarities in narrative arc. This is the stock narrative of election, a story of fall and redemption that was embedded in contemporary self-understandings of both Jews and Christians-at least through the twelfth century-as both intellectually competed with one another for the mantle of "God's Chosen People." All that differed in I096 was that they, respectively, saw themselves at different points in the timeline-Christians saw their path ascending, while the Jews of the Rhineland thought their arc still pointed down.

This short paper will briefly consider the notion of election-the belief that a group has a special place in the arc of sacred history-as it was manifested by medieval European Christians, specifically in the period surround-

${ }^{1}$ See Matthew Gabriele, "Against the Enemies of Christ: The Role of Count Emicho in the Anti-Jewish Violence of the First Crusade," in Christian Attitudes toward the Jews in the Middle Ages: A Casebook, ed. Michael Frassetto (New York: Routledge, 2006), 6I-82. Most recently, see Robert Chazan, “'Let Not a Remnant or a Residue Escape': Millennarian Enthusiasm in the First Crusade," Speculum: A Journal of Medieval Studies 84, no. 2 (2009): 289-3 I 3; and Jay Rubenstein, Armies of Heaven: The First Crusade and the Quest for Apocalypse (New York: Basic Books, 20 I I), 45-53.

${ }^{2}$ The best discussion of these events from the Jewish perspective remains Jeremy Cohen, Sanctifying the Name of God: Jewish Martyrs and Jewish Memories of the First Crusade (Philadelphia: University of Pennsylvania Press, 2004).

${ }^{3}$ Matthew Gabriele, An Empire of Memory: The Legend of Charlemagne, the Franks, and Jerusalem before the First Crusade (Oxford: Oxford University Press, 20 I I). 
ing the First Crusade. Then, at the end, I will turn briefly to think about what this could mean for issues of self-conceptualization among contemporary American (Judeo-)Christians of the twenty-first century. Because the narrative of election has historically been so similar in its contours, understanding the medieval mentality may help us understand the implications of these beliefs in modern America.

It is, I would argue, of only marginal utility to first look to the Bible in order to understand eleventh-century Christian conceptions of what it meant to be a "chosen people." Scholars have the tendency to treat medieval authors as thinking sola scriptura. But medievals encountered the Bible through art, through the liturgy, and especially through patristic and later exegesis, so that each verse was always encumbered with interpretation. In the eleventh century, the medieval Christian understanding of election came largely from the late eighth- and early ninth-century Franks, who conceived of themselves as the novus Israel. Mary Garrison's compelling article on the creation of this Frankish identity argues that election can be used both to universalize and to particularize. ${ }^{4}$ In the case of the ninth-century Franks, their status as the "new Israel" did a number of things. It intellectually separated them from non-Christians, including Jews, Muslims, Saxons, and Avars, justified Frankish violence against those groups - as well as other Christian groups such as the Lombards and Bavarians - and simultaneously allowed that the conquered (and/or converted) could be subsumed. This particular intellectual stance meant that Frankish identity spread throughout most of Western Europe in the centuries succeeding Charlemagne's death in $8 \mathrm{I} 4 \mathrm{CE}$, uniting disparate peoples through a collective memory of a shared golden age. As the abbot Guibert of Nogent wrote even as late as I IOO CE, "Because [the name 'Frank'] has carried the yoke since the days of its youth, it will sit in isolation [Lam 3.27-28], a nation noble, wise, war-like, generous, [and] brilliant

${ }^{4}$ Mary Garrison, "Divine Election for Nations-A Difficult Rhetoric for Medieval Scholars?," in The Making of Christian Myths in the Periphery of Latin Christendom (c. I000-1300), ed. Lars Boje Mortensen (Copenhagen: Museum Tusculanum Press, 2006), 276-77. On ninth-century biblical exegetes becoming "gatekeepers" of meaning for the Fathers and so for the Bible itself, see Silvia Cantelli Berarducci, "L'esegesi della Rinascita carolingia," in La Bibbia nel Medioevo, ed. Giuseppe Cremascoli and Claudio Leonardi (Bologna: Edizioni dehoniane, 1996), 198; and Matthew Gabriele, "The Last Carolingian Exegete: Pope Urban II, the Weight of Tradition, and Christian Reconquest," Church History 8I, no. 4 (2012): in press. 
above all kinds of nations. Every nation borrows the name as an honorific title; do we not see the Bretons, the English, [and] the Ligurians call men 'Frank' if they behave well?"5

Guibert's citation of these verses from Lamentations points us towards another critical facet of the notion of election. As Garrison writes, we should be aware how it "affirms a belief in the abiding presence and intervention of God in history ... so that the present is not merely a re-enactment, but also in some sense a fulfillment of words and events of the Bible. For some self-defined elect groups ... their own contemporary history could be read for signs of divine approval and disapproval." ${ }^{6}$ Events were always pregnant with meaning. God could, at any moment, either restore-or removehis favor. Lam 3 speaks of this cycle of fall and redemption explicitly, with the Israelites tasting God's wrath then regaining his favor through the Lord's compassion at his people's repentance. Here, the Franks of the ninth, tenth, and eleventh centuries explicitly rejected Augustine's idea that current events were somehow "outside" sacred history. ${ }^{7}$ But it was also a justification for the Franks to read events backwards and typologically, intellectually harmonizing past, present, and future. What we do now has been done before, and will be done again.

Therefore, when talking about "chosen peoples," it is particularly important to understand the historical narrative that a people constructed for themselves. How these groups tell the story of their past, in conjunction with how they tell the story of their future, shapes how they may act in the present. For the Franks, the story began with the ascent of the Carolingians in the eighth century, Pepin the Short as Saul, leading to their unconquered "Davidic" ruler (Charlemagne) in the early ninth century, a man just crowned Roman emperor in $800 \mathrm{CE}$, a people granted victory over all their enemies, with an empire that stretched from Rome to the English Channel and from Catalonia to Saxony, and an intellectual class that conceptualized the bound-

${ }^{5}$ Guibert of Nogent, Dei gesta per Francos, ed. R. B. C. Huygens, CCCM, I 27A (Turnhout: Brepols, 1996), I08-10. English translation from Guibert, The Deeds of God through the Franks, trans. Robert Levine (Woodbridge: Boydell \& Brewer, I997), 4I. See also Gabriele, Empire of Memory, particularly chapter 4.

${ }^{6}$ Mary Garrison, "The Franks as the New Israel? Education for an Identity from Pippin to Charlemagne," in The Uses of the Past in the Early Middle Ages, ed. Yitzhak Hen and Matthew Innes (Cambridge: Cambridge University Press, 2000), I 7 .

${ }^{7}$ See R. A. Markus, Saeculum: History and Society in the Theology of St. Augustine (Cambridge: Cambridge University Press, 1970), 2 I-22; and Garrison, "Divine Election for Nations," $284-85$. 
aries of christianitas ("Christianity") as coextensive with those of the empire. But David was followed by Solomon, and then by Jeroboam. The Frankish empire, like the Israelites' kingdom, splintered and devolved into civil war. A new "exile" began - a new time of the prophets, a time of new Daniels and new Jeremiahs. This was the late ninth and tenth centuries, when bishops and monks (as these new prophets) cried out for the loss of the empire, for the loss of their Jerusalem, cried out against the collective sins of the new chosen people, hoping for repentance and the return of God's favor. ${ }^{8}$ Critically, however, they believed - unshakably believed — that God's favor would return.

For example, the exegetical tradition of Dan 2:2 I ("God changes times and ages; erects and transforms kingdoms") is instructive. Jerome had read the verse to mean that God's will governed empires as well as men, and that the verse pointed forward to the latter half of Dan 2 (Nebuchadnezzar's dream of the statue) and the decline of kingdoms. God allowed evil men to do evil things in order to punish the wicked. ${ }^{9}$ Almost all subsequent early medieval exegetes understood the verse similarly. But then, sometime during the 840 s, as the Frankish kingdom was breaking apart, Haimo of Auxerre slightly altered this tradition. He read Dan 2:2 I to say that God allowed evil men to rule in order to punish the wicked, but also to steel the elect. Good men were tested by evil and emerged as better men. For Haimo, the arc of sacred history was inverted, more like a parabola-a descent of kingdoms, followed by a rebirth. ${ }^{10}$ This was the cycle of election; God's hand was there, just waiting for the actions of the chosen people to merit its restoration.

The Franks of ca. 900, suffering under the pagans, in a fragmented kingdom, still thought of themselves as the new chosen people; and the Franks of the rogos thought of themselves as the chosen people as they marched against God's enemies down the Danube, across Asia Minor, through Syria, and over the walls of Jerusalem. The contemporary Christian narratives of the First Crusade, all written after the taking of Jerusalem in I099, read his-

${ }^{8}$ Mayke de Jong, The Penitential State: Authority and Atonement in the Age of Louis the Pious, 8I4-840 (Cambridge: Cambridge University Press, 2009), I02-I I, I 46-47, I66-69; and Paul Edward Dutton, The Politics of Dreaming in the Carolingian Empire (Lincoln: University of Nebraska Press, 1994), 199-200; among others.

9 Jerome, In Danielem, ed. Francisco Glorie, CCSL, 75A (Turnhout: Brepols, 1964), 787. For more on Jerome's commentary, see Régis Courtray, Prophète des temps derniers: Jérome commente Daniel (Paris: Beauchesne, 2009).

${ }^{10}$ See the full discussion in Gabriele, "Last Carolingian Exegete." 
tory backwards, seeing in the actions of the Franks moments where prophecy seemed to be on the cusp of fulfillment. For example, the Auvergnat priest and crusade participant Raymond d'Aguiliers wrote that the Franks' victory at Antioch proved God's covenant with his people. ${ }^{11}$ Then, Raymond noted that during the sack of Jerusalem:

Piles of heads, hands, and feet were to be seen in the streets of the city ... But these were small matters compared to what happened at the Temple of Solomon, a place where religious services are ordinarily chanted ... [L] et it suffice to say ... that in the Temple and porch of Solomon, men rode in blood up to their knees and bridle reins. Indeed, it was a just and splendid judgment of God that this place should be filled with the blood of the unbelievers, since it had suffered so long from their blasphemies. ${ }^{12}$

Although the massacre described in this passage has long been noted, only recently have scholars began to see significance in Raymond's invocation of Rev I 4:20 ("And the wine press was trodden outside the city, and blood flowed from the wine press, as high as a horse's bridle"). ${ }^{13}$ Here, the actions of men occupy a specific moment of sacred time and are to be read typologically. Isa 63:I-6, Rev I 4:I 4-20, the events of I 999 CE, the coming End: the actions of the new chosen people occurred within sacred history, provisionally fulfilling prophecy and prefiguring the "real" events that will occur at the End.

\section{$\operatorname{son}$}

In some ways - in many ways-Christians of the twenty-first century understand themselves quite differently from their predecessors. But there are similarities as well. Some strains of modern American evangelical Christianity have the tendency to think themselves the direct heirs, without intermediaries, of first-century CE Jewish-Christians from Palestine. ${ }^{14}$ One manifestation of this can be seen in the "Holy Land Experience" theme park in

${ }^{11}$ Pons of Balazun and Raymond d'Aguiliers, Historia Francorum qui ceperunt Iherusalem, ed. John Hugh Hill and Laurita L. Hill (Paris: P. Geuthner, I969), 79-80.

${ }^{12}$ Ibid., I 27-28.

${ }^{13}$ See especially the discussion of 1099 in Benjamin Z. Kedar, "The Jerusalem Massacre of 1099 in the Western Historiography of the Crusades," Crusades 3 (2004): 1 5-76; and Rubenstein, Armies of Heaven, 286-92.

${ }^{14}$ Elizabeth A. Castelli, Martyrdom and Memory: Early Christian Culture Making (New York: Columbia University Press, 2004), I90. 
Orlando, FL (run by Trinity Broadcasting Network), where one can walk the recreated streets of ancient Jerusalem, talk to centurions and apostles in costume, and celebrate a seemingly benign, commercialized supersessionism with trinkets from the gift shop. Everything "Judeo-Christian" is actually Christian: a "new Covenant" talit or mezuzah, or a magnet with the Star of David and menorah merging gracefully into the icthys (the "Christian fish"). ${ }^{15}$ The park's description of the Passover feast explains how Jews had been commemorating the Trinity all along.

This is an explicit rejection of the actual past in service of a new narrative, a new memory, ${ }^{16}$ a hermeneutic "Judeo-Christianity" that returns the modern man to the period before the "parting of the ways," as if the modern Christians who arrive at the theme park in their tour busses can simply skip over two millennia of history and return to a moment of promise, atoning for the Israelites' mistaken rejection of Jesus and restoring a "proper" worship of the Lord to America. Indeed, during the climactic theatrical reenactment of the crucifixion that occurs just before the park's closing every day, a centurion walks among the assembled crowd of tourists to directly confront them, asking them first (during the arrest in Gethsemane) if they too were followers of Jesus, thereby giving the crowd the opportunity to atone for Peter's denial. Then, after the discovery of the empty tomb, the centurion once again walks into the crowd to ask these twenty-first-century Americans if they accepted the truth of what they had just "witnessed" (the resurrection). The centurion then leads the crowd, those who have temporarily gone back in time to avoid the Jews' initial mistake in rejecting Jesus, the new chosen people, in a profession of faith. ${ }^{17}$

Here, just as in the eleventh century, election both universalizes and particularizes. All who witness the spectacle are assumed back to first-century Jerusalem to witness Jesus' death and resurrection. All the attractions work together to reinforce this connection. One of the them, called "The Scriptorium," begins its tour of sacred texts in Babylon with the prophet Daniel and ends (perhaps better, "culminates") in eighteenth-century America. ${ }^{18}$ But

${ }^{15}$ One can see a selection of the material at their online store: http://www. holylandexperience.com/store_section/featured_products.html.

${ }^{16}$ Here I use Keith Michael Baker's astute demonstration (drawing from Maurice Halbwachs) of the fluidity between memory and history-history is memory contested; memory is history controlled and fixed. See Keith Michael Baker, Inventing the French Revolution (Cambridge: Cambridge University Press, I990), 56.

${ }_{17}$ Personal visit to Holy Land Experience, April 20 I I.

${ }^{18}$ See http://www.holylandexperience.com/exhibits/the_scriptorium.html. 
the visitor is left with the distinct impression that little has changed. There is no history here; only memory. The narrative of salvation is linear, coherent, and meaningful. It is virtually unchanging, an Augustinian conception in which God manifested his favor towards the chosen people-Israelites became Palestinian Christians became Englishmen became (Protestant) Americans. Each time God chastised the chosen people with an enemy-Romans against the Israelites, Jews against the Palestinian Christians, Catholics against the Protestants, Secularists against Christians—-the chosen people emerged reborn, steeled in their resistance to evil.

This intellectual connection to the first century CE and the narrative of a persecuted "Judeo-Christianity" can go some way, I think, to explaining fervent Pentecostal evangelical support for the state of Israel. Texas governor Rick Perry, for example, expressed this elision well when he said, "I ... as a Christian have a clear directive to support Israel. So from my perspective ... both as an American and as a Christian, I am going to stand with Israel." ${ }^{9}$ American Richard Landes expressed the same idea but from the reverse perspective; anti-Zionism, he argues, always comes with anti-Americanism. ${ }^{20}$ The thinking here might be that Israelis (not necessarily "Jews") are after all nearly Christians, and we both-Americans and Israelis-face the same external enemy, in the form of Islam. ${ }^{21}$ This enemy made itself apparent on 9/I I, when God's wrath descended upon the new chosen people for their sins. ${ }^{22}$ The new (American) Republican Party orthodoxy of "American Exceptionalism," an "exclusivist political religion ... that demands obligatory and unconditional support, and condemns any perceived disrespect," fits well within this paradigm. ${ }^{23}$

${ }^{19}$ William Saletan, "Alliance for Christ: Rick Perry's Pledge to Stand with Israel 'As a Christian' is a Gift to Islamic Extremists," Slate, September 2 I, 20 I I, http://www.slate.com/ articles/news_and_politics/frame_game/20 I I/og/alliance_for_christ.html.

See also the July $201 \mathrm{I}$ comments of all the 2012 Republican presidential candidates to the Republican Jewish Coalition at http://www.haaretz.com/news/international/ live-blog-u-s-presidential-candidates-speak-at-the-republican-jewish-coalition-I.400 I 75.

${ }^{20}$ Richard Landes, "Final Battle," Tablet, August 3 I, 20 I I, http://www.tabletmag.com/ news-and-politics/765 I I/final-battle.

${ }^{21}$ Victoria Clark, Allies for Armageddon: The Rise of Christian Zionism (New Haven: Yale University Press, 2007); and also more generally the wonderful essays in Jason Dittmer and Tristan Sturm, eds., Mapping the End Times: American Evangelical Geopolitics and Apocalyptic Visions, Burlington (Ashgate, 2010).

${ }^{22}$ John F. Harris, "God gave U.S. 'What We Deserve,' Fallwell Says," The Washington Post, September I 4, 200I, http://www.washingtonpost.com/ac2/wp-dyn/A28620-200 ISep 4.

${ }^{23}$ Mark Silk, "American Exceptionalism and Political Religion in Republican Politics 
It may seem curious that this perspective has even now enshrined by the American left. Mark Silk's historical discussion of the "Judeo-Christian tradition" may help us understand why such a move transcends common political difference. ${ }^{24}$ The term "Judeo-Christian" seems to always be called into service at particular moments of stress, when a community finds itself besieged-either in perception or reality. Judeo-Christians against fascism, against communism, against secularism. "Judeo-Christian" seems to spring up when enemies seem to emerge against the chosen people. ${ }^{25}$ For example, a new book by Todd Gitlin and Liel Leibovitz, The Chosen Peoples: America, Israel, and the Ordeals of Divine Election argues that much violence in the world derives from those who challenge America and Israel's inherent connection as chosen peoples. ${ }^{26}$ If you are not for God's new chosen people, you are against them.

The Chief Rabbi, Lord Sacks, recently made the complementary point to this case. He wrote, "The question is not radical Islam but, does the West believe in itself any more? ... 'We have met the enemy,' said the cartoon character Pogo, 'and he is us.' That is the challenge of 9/I I." ${ }^{27}$ When things go wrong for the chosen people, the cause is the chosen people's sin but the consequence is manifested in the suffering caused by external attacks. It doesn't really matter who those outside groups are (in the tenth century, Vikings and Muslims were thought to have been cut from the same cloth), because in the end, they are all the same enemy, acting unwittingly as agents of God's wrath. And the way back into favor is through repentance and resistance.

Resistance can take spectacular forms, such as when Erik Prince and his company, Blackwater, specifically sought to recruit ex-soldiers who shared Prince's understanding of the American wars in Iraq and Afghanistan as Chris-

Today," The Review of Faith and International Affairs 10, no. 2 (2012): 39, doi:10. 1080/ I 5570274.2012 .6825 I 6 .

${ }^{24}$ See the seminal paper by Mark Silk, "Notes on the Judeo-Christian Tradition in America," American Quarterly 36, no. I (1984): 65-85.

${ }^{25}$ And we ought remember that this is a critical component to a group's selfconceptualization as elect. For example, see the wonderful Castelli, Martyrdom and Memory, especially $\mathrm{I} 72-203$.

${ }^{26}$ Todd Gitlin and Liel Leibovitz, The Chosen Peoples: America, Israel, and the Ordeals of Divine Election (New York: Simon \& Schuster, 2010), especially I 47-8I.

${ }^{27}$ Jonathan Sacks, "How to Reverse the West's Decline," Standpoint, September 20 I I, http://www.standpointmag.co.uk/node/4049/full. 
tian wars of extermination against Islam, ${ }^{28}$ or American Lieutenant General "Jerry" Boykin going, in full uniform, on a preaching tour of American churches, where he spoke of Muslims worshipping an "idol" and "false god" and portraying America's battle against militant Islam as a battle against "Satan." 29 But resistance can also take the form of purposefully re-posting the Ten Commandments in a public school after the threat of a lawsuit. ${ }^{30}$ This latter course may seem rather banal but the problem is that there is really only a difference of degree between types of resistances. The idea of election is a tautology. It explains everything because it is an explanation in and of itself. God's favor is seen in victories, and his wrath felt in the sting of defeat. When you win, you're the chosen people. When you lose, you're definitely the chosen people. And if a people think of themselves as chosen, what isn't inside is outside and what is outside was sent by God against them. And those outsiders are a test that must, ultimately be overcome. One way or another.

28 "Erik Prince and the Last Crusade," Democracy in America: American Politics, August 6, 2009, http://www.economist.com/blogs/democracyinamerica/2009/08/erik_prince_and_ the_last_crusa.

${ }^{29}$ Brian Knowlton, "General Compares Militants to 'Satan'," International Herald Tribune, 20 I0, 2003; and William M. Arkin, "The Pentagon Unleashes a Holy Warrior," Los Angeles Times, I6 I0, 2003. Boykin has now defended himself in Jerry Boykin and Lynn Vincent, Never Surrender: A Soldier's Journey to the Crossroads of Faith and Freedom (New York: Faithwords, 2008). More generally, see Jeff Sharlet, "Jesus Killed Mohammed: The Crusade for a Christian Military," Harper's, May 2009.

${ }^{30}$ For example, see Katelyn Polantz, "Giles County Decision on Ten Commandments Display Stirs Fight," The Roanoke Times (June 9, 201 I), http://www.roanoke.com/news/ roanoke/wb/289227; and particularly Laurence Hammack, "Ten Commandments Display is Private Speech, Lawyers Say," The Roanoke Times (October 20, 20I I), http://www.roanoke. $\mathrm{com} /$ news/roanoke/wb/299936, where the Liberty Counsel's lawyer says that the ACLU's case "is motivated by a desire to cleanse Giles County of any vestiges of the Ten Commandments." 